\title{
A RESISTÊNCIA DOS TRABALHADORES NOS CANAVIAIS ALAGOANOS
}

\section{LA RESISTENCIA DE LOS TRABAJADORES EN LOS CAMPOS DE CAÑA DE ALAGOAS}

\section{THE WORKERS' RESISTENCE IN ALAGOAS' SUGAR CANE PLANTATION}

\author{
Lúcio Vasconcellos de Verçoza \\ Doutorando do Programa de Pós-Graduação em Sociologia \\ Universidade Federal de São Carlos. \\ luciovercoza@yahoo.com.br
}

Maria Aparecida de Moraes Silva ${ }^{1}$

Professora Colaboradora do Programa de Pós-Graduação em Geografia

Universidade Estadual Paulista - UNESP / P. Prudente Colaboradora do Programa de Pós-Graduação em Sociologia

Universidade Federal de São Carlos - UFSCar

Pesquisadora do CNPq. maria_moraes@terra.com.br

Resumo: O mais recente processo de reestruturação produtiva da agroindústria canavieira alagoana - iniciado a partir dos anos 1990 - alterou profundamente os critérios de seleção dos trabalhadores, a organização do trabalho e a sua forma de gestão. Essas mudanças, que afetam diretamente os trabalhadores, resultaram em intensificação do ritmo de trabalho, elevação de sua produtividade e diminuição do número de empregos. Em face dessas novas configurações da relação capital e trabalho, o objetivo do presente artigo é analisar as formas de resistência construídas pelos trabalhadores canavieiros em Alagoas. Para atingir tal escopo, foram realizadas pesquisas de campo e entrevistas com cortadores de cana, operadores de carregadeiras, cabos (fiscais) e dirigentes de sindicatos de trabalhadores rurais.

Palavras-chave: Trabalho rural. Agroindústria canavieira. Migrantes. Luta de classes. Mecanização.

Resumen: El más reciente proceso de restructuración del sector sucroalcoholero de Alagoas - iniciado en la década de 1990 - ha alterado profundamente los criterios de selección de los trabajadores, la organización y gestión del trabajo. Estos cambios, que afectan directamente a los trabajadores, resultaron en aceleración del ritmo de trabajo, aumento de la productividad y disminución del número de puestos de trabajo. A la luz de estas nuevas configuraciones de la relación capital y trabajo, el objetivo de este artículo es analizar las formas de resistencia construidas por los trabajadores de la caña de azúcar en Alagoas. Para lograr este objetivo, se llevó a cabo la investigación de campo y entrevistas con los cortadores, operadores de carga, fiscales y los líderes de los sindicatos de trabajadores rurales.

Palabras clave: Trabajo agrícola. Sector sucroalcoholero. Migrantes. Lucha de clases. Mecanización.

\footnotetext{
${ }^{1}$ Autora do livro: Errantes do Fim do Século, EDUNESP, 1999.
} 


\begin{abstract}
The most recent process of productive restructuration of Alagoas' sugarcane agro industry - initiated in the 1990 - modified profoundly the criterions of workers selections, the labor organization and its way of management. Those changes, which affect directly the workers, resulted in the intensification of the work rhythm, elevation of its productivity and decrease of job numbers. In the core of those configurations in the relationship between capital and work, the purpose of the present article is to analyze the ways of resistance constituted by the sugarcane worker in Alagoas. To achieve this purpose, were realized field research and interview with sugarcane cutters, brail operator, inspectors and leaders of rural labor union.
\end{abstract}

Keywords: Rural work. Sugarcane agro industry. Migrants. Class struggle. Mechanization.

\title{
Introdução
}

Várias pesquisas têm demonstrado que as novas configurações produtivas da agroindústria canavieira brasileira caminham atreladas à intensificação da exploração da força de trabalho e à degradação da saúde do trabalhador (ALVES, 2007; LAAT, 2010; NOVAES, 2007; PLANCHEREL et al. 2011; SILVA, 2007, 2012). No bojo das recentes transformações no mundo do trabalho nos canaviais brasileiros, encontra-se o emprego de trabalhadores dotados de um perfil altamente produtivo e submetidos a novos mecanismos de organização e controle/disciplinamento do trabalho. Esses fatores, aliados ao método de remuneração por produção, tendem a fazer com que o trabalhador, mesmo recebendo parcos salários, intensifique ainda mais o ritmo de trabalho.

No tocante especificamente à agroindústria canavieira de Alagoas, o seu mais recente processo de reestruturação produtiva teve como marco fundamental o início da década de 1990, mais precisamente no contexto da extinção do Instituto do Açúcar e do Álcool (IAA). Diante da desregulamentação estatal, as usinas de Alagoas foram obrigadas a se reestruturar produtivamente para sobreviver à forte concorrência intercapitalista, marcada por um grande atraso das usinas alagoanas (em termos de produtividade) quando comparadas às do sudeste (CARVALHO, 2000).

A elevação da produtividade da agroindústria canavieira alagoana - assim como ocorreu nas usinas paulistas - não foi alcançada apenas mediante a incorporação de novas tecnologias, as mudanças na forma de gestão e organização do trabalho também foram fundamentais para a efetivação dessa meta e para a redução no número de empregos gerados (PADRÃO, 1997; MELLO, 2002). 
Dentre algumas dessas mudanças na parte agrícola, estão: a exigência de uma média mínima de toneladas diárias de cana cortada $^{2}$ e o cumprimento de um rígido padrão de qualidade do corte da matéria-prima. ${ }^{3}$ Essas exigências são acompanhadas tanto por um aumento do controle do processo de trabalho e da disciplina por parte do capital agroindustrial canavieiro, quanto pela elevação do dispêndio de energia não remunerado por parte do trabalhador. Ademais, caso constatado o não cumprimento dos padrões exigidos, daí segue-se uma série de punições que pode resultar na não contratação do trabalhador na safra seguinte. Como resistir nessas circunstâncias?

Será que as recentes transformações do trabalho nos canaviais estão ocorrendo sem encontrar resistência dos trabalhadores? Seria um ledo engano imaginarmos que os trabalhadores canavieiros são completamente submissos e resignados em relação à intensificação da exploração-dominação da força de trabalho. Mas, se existe resistência nos canaviais alagoanos, como ela se processa? Como os usineiros reagem diante das ações de resistência? Quais são os atuais rumos da luta dos trabalhadores canavieiros em Alagoas? São essas questões que objetivamos analisar no presente artigo.

\section{Os "trabalhadores desenquadrados"}

Iniciaremos investigando como os trabalhadores reagiram diante do mais recente padrão técnico de qualidade exigido no corte da cana que, ao aumentar a produtividade agrícola e industrial da matéria-prima, tende, paralelamente, a rebaixar o seu salário (que é determinado somente pelo quantum de cana cortada). Além disso, caso constatado o não cumprimento do padrão exigido, existe o risco de o trabalhador ser punido.

Mas será que o risco de punição acarreta cumprimento à risca dos padrões exigidos? Em caso de não cumprimento dessas normas preestabelecidas, quais as táticas utilizadas pelos trabalhadores para evitar punições? Os trabalhadores que burlam os

\footnotetext{
${ }^{2}$ A exigência de média mínima diária de toneladas excluiu as mulheres do corte da cana - semelhante ao que ocorreu em São Paulo (SILVA, 2011). Atualmente o número de cortadoras de cana em Alagoas é insignificante.

${ }^{3} \mathrm{O}$ padrão de qualidade exigido no corte consiste em: 1) cortar a cana o mais rente possível ao chão para evitar perda de sacarose ("toco baixo"); 2) a parte superior da cana (ponta ou ponteiro) deve ser cortada em um local preciso para que seja processada apenas a parte da matéria-prima rica em sacarose ("ponteiro tirado no ar"); 3) arrumar a cana cortada em local bem afastado das palhas para que os guinchos recolham apenas a cana, evitando o processamento de organismos minerais e vegetais indesejáveis ("palha afastada da esteira").
} 
padrões estão sujeitos a quais punições? Para elucidar essas questões, achamos válido recorrer aos seguintes trechos da entrevista ${ }^{4}$ com um cabo (fiscal) e recrutador de trabalhadores da usina Seresta ${ }^{5}$ :

Pesquisador [P]: Começou a partir de que ano isso [exigência de novos padrões no corte da cana]?

Entrevistado [E]: Começou... foi lentamente. Mas firme mesmo... firme mesmo, nós estamos aí com uns dez anos. A [usina] Seresta está com uns dez anos. Outras usinas estão com menos. [...] Quando a gente apertava um trabalhador aqui... assim, quando o trabalhador não se enquadrava aqui, ele ia "s'imbora" para [usina] Guaxuma.

P: E no começo foi difícil [exigir o novo padrão de corte da cana]?

E: Ah, muito difícil! Muito difícil...

P: Como era a reação dos trabalhadores?

E: A reação era demais [os trabalhadores argumentavam]: "Rapaz, nós, toda vida cortamos desse jeito. As usinas moíam e faziam muito açúcar, faziam muito dinheiro, e agora por que isso?"

P: Tinha muita confusão na época?

E: Muita confusão... foram perdidos milhões ou trilhões de sacos de açúcar. Só não fazia demais, mas o toco era aqui ó, toco alto. Perdia uma tonelada de cana por hectare [...] Naquela época, era uma tonelada e duzentos por hectare [de cana que não era moída], e hoje nós baixamos para sessenta quilos, porque tem uma análise também [...] Era toco alto, não tinha limpeza, despontamento. Quem comandava a mão-de-obra queria era manter a usina moendo: produção. Mas hoje é diferente: é produtividade hoje. Quer dizer: ter quantidade e qualidade.

[...]

Entrevistado (E): Todas as turmas têm um "maceteiro". Quando eles não encontram jeito eles desistem.

Pesquisador (P): Mas quais são as técnicas que eles utilizam para tentar ludibriar...

E: Primeira, é fazer o toco alto [não cortar a cana rente ao solo] na carreira [rua] do meio.

P: E depois cobre?

E: E depois cobre [com as canas cortadas]. Outros não deixam a cana atravessada, deixam ela no comprido e depois cobrem com as outras... bem cobertinha...

P: Como é no comprido?

E: Por exemplo: A linha da carreira de cana é pra lá, então tem que cortar e deixar ela assim; atravessada [no sentido transversal a carreira de cana] para a carregadeira de cana pegar.

P: Entendi. Todas na mesma posição.

\footnotetext{
${ }^{4}$ Os nomes dos entrevistados não serão revelados para evitar qualquer tipo de retaliação que porventura possa ocorrer contra os entrevistados. Por isso, todos os nomes citados nas entrevistas foram substituídos por outros fictícios.

${ }^{5}$ Essa entrevista foi realizada em fevereiro de 2011, no município de Teotônio Vilela, localizado na Microrregião dos Tabuleiros de São Miguel dos Campos, principal área produtora de cana-de-açúcar de Alagoas. A usina Seresta também está situada nesse município.
} 
E: Eles aqui saem derrubando elas retas. Por cima bota outras atravessadas que fica tão bem feito que não dá pra ver [as que estão por baixo na posição fora do padrão exigido].

P: Mesmo um cabo experiente pode ser enganado?

E: Pode. Porque às vezes é uma pessoa que não lhe deu problema nenhum. Aí você nem desconfia.

P: E qual é o problema que causa?

E: A carregadeira pega a cana que está atravessada e a que está no comprido fica. [...] Então, em toda turma a gente encontra esse tipo de gente. O que é que a gente faz: no outro dia se a gente está perto... Nós temos uma chamada de pessoas por ordem. Então amanhã eu já sei por aquele carregadeiro que tirou. Então a gente chama aquela pessoa, e diz: olhe o que você fez. Ele diz: "Rapaz, eu não faço um serviço desses". Aí eu digo: "Vamos olhar aqui a frequência: José, Sebastião, Antônio, Pedro: quarto eito". Aí ele diz: "Rapaz, estou envergonhado, viu. Eu não sei como eu fiz isso". Mas ele fez consciente, sabe? Então a gente vai eliminando.

P: Um trabalhador que faz isso com frequência, o que acontece quando ele te procura na próxima safra em busca de emprego na sua turma?

E: Olhe, infelizmente aquele que me dá mais trabalho durante uma moagem... se ele me der trabalho em quinze dias, num mês, e eu consegui deixar ele no padrão, no outro ano ele é bem vindo. Mas aquele [que não se encaixa no padrão] que vem no outro ano, eu sabendo que vou ter o mesmo trabalho... Eu não digo a ele que não vou pegar a carteira [de trabalho] dele porque ele fez aquilo, mas aí eu digo: "Rapaz, infelizmente está completo já. Agora se surgir uma vaga eu sei o seu endereço e vou buscar. Mas não me espere, se aparecer outro você pega". Então a gente faz isso, porque quando você passa uma moagem... Pronto, eu hoje tenho um que me dá trabalho nessa safra $[\ldots]$.

P: O trabalho que ele lhe dá é qual? É trabalhar fora da norma?

E: Hoje ele faz bem feito, e amanhã ele faz malfeito. Ele começa o eito bem feitinho e amanhã ele faz malfeito. Então ele está assim desenquadrado. Dá trabalho. Nós já estamos com cinco... completando cinco meses no dia onze, e infelizmente eu não consegui...

P: Mudar a conduta dele...

E: Não. Não dá pra mudar não. Esse na próxima... [nesse momento o entrevistado balança a cabeça com um sinal de negativo] É só trabalhar esses seis meses com ele. Ele é assim: ele caça uma coisa pra fazer errado. Ele diz assim: "Realmente se fosse outro cabo já tinha me botado pra fora. Mas de agora em diante vou trabalhar direitinho." Mas passa uma semana e ele erra novamente.

P: Ele é novo, ou já é um trabalhador experiente?

E: Ele já é um cara experiente. É que ele quer mesmo caçar um jeito... uma facilidade. Por que veja só: o trabalho malfeito tem mais produção. No bem feito o trabalhador faz menos.

Decidimos transcrever esses longos trechos da entrevista porque deles podemos extrair uma descrição da dominação e da resistência como processos que se efetivam no dia-a-dia do trabalho no eito. A chegada da exigência de novos padrões de corte da cana não foi bem aceita pelos trabalhadores. Como afirma o entrevistado, a sua 
consolidação se deu lentamente, uma vez que os trabalhadores não lidavam docilmente com o novo processo de trabalho. As reclamações dos trabalhadores eram constantes durante os primeiros anos. Para não se submeterem aos novos padrões de produtividade, alguns cortadores de cana procuravam emprego em usinas que ainda não tinham redefinido o processo de trabalho. Mas, aqueles que permaneciam na usina e não cumpriam o novo padrão do corte da cana, estavam sujeitos a descontos salariais e ao grande risco de serem "eliminados" (não serem contratados na safra seguinte). Essas formas de punição, que afetam diretamente a reprodução social dos trabalhadores, foram fundamentais para consolidar o novo padrão de produtividade.

Porém, isso não implica supor que os trabalhadores tenham ficado completamente "enquadrados" pelas novas normas. Como sugere o conceito de experiência proposto por Thompson (1981), os trabalhadores experimentam essa situação determinada por outrem (é uma determinação externa, não foram os trabalhadores que escolheram esses novos padrões de produtividade e acumulação) e reelaboram essa experiência em sua consciência e, em seguida, agem sobre essa situação determinada.

Aqueles que o cabo denomina como "maceteiros", ou "desenquadrados" são precisamente os trabalhadores que, mesmo sabendo dos riscos de severas punições, optam por burlar o padrão técnico exigido no corte. Mas essas ações individuais de boicote ocorrem dentro de certos limites de possibilidades determinadas pela própria condição de assalariado: o boicote não pode ser efetuado de modo integral, pois acarretaria demissão. Nessas circunstâncias, os "trabalhadores desenquadrados" descumprem o padrão dentro do limite de que o mesmo aparente estar sendo cumprido. Desse modo, tanto o boicote ocorre de modo incompleto, quanto o padrão exigido não se materializa por inteiro. Essa forma de resistência é eficaz somente enquanto ela não for notada pelos fiscais, enquanto não seja percebida como forma de resistência.

Por isso, a "atividade desenquadrada" ocorre preferencialmente no centro do talhão e na rua central (do meio) do eito ${ }^{7}$. A escolha do primeiro lugar decorre de sua localização afastada das rodagens $^{8}$ e, portanto, mais longe dos olhos dos cabos e de outros superiores. Já a preferência pela rua central deve-se à possibilidade de as canas

\footnotetext{
6 O termo "maceteiro" é derivado da palavra macete, e neste caso é empregado para adjetivar os trabalhadores mais indisciplinados.

${ }^{7}$ Eito é como costuma ser denominado o local em que cada trabalhador do corte da cana executa o seu trabalho. Ele tem um formato retangular e é composto por determinado número de ruas (fileiras) de cana.

${ }^{8}$ Como são localmente denominadas as estradas de terra nas quais circulam os ônibus e máquinas.
} 
"mal cortadas" serem encobertas (camufladas) pelas das outras ruas, no momento de arrumação da matéria-prima cortada.

As "práticas desenquadradas" que nos foram mais relatadas, tanto pelos trabalhadores "da rua", quanto pelos sertanejos, são: deixar os tocos altos na rua do meio (parte da cana que não foi cortada); arrumar a cana cortada em sentido não uniforme (isso dificulta o transporte das carregadeiras); não cortar todas as ponteiras da cana; tombar as canas com os pés (desse modo, ela continua ligada à raiz); picar a cana em vários pontos (geralmente ocorre quando o eito tem canas deitadas). Esse tipo de prática, que também é realizada amiúde nos canaviais paulistas (SILVA, 1999, 2008; COVER, 2011), foi denominada, por Silva, como "resistência miúda", que é aquela que “ocorre nos poros do sistema de dominação e exploração" (2008: 31).

Ações como essas estariam no bojo do que Scott denominou de "formas cotidianas de resistência” que consistem em: “ 'fazer corpo mole', a dissimulação, a submissão falsa, os saques, os incêndios premeditados, a ignorância fingida, a fofoca" (SCOTT, 2002: 12). A falsa submissão é um elemento importante, pois mesmo quando a "resistência miúda" (SILVA, 2008) é identificada pelo cabo, o trabalhador nega veementemente: "Rapaz, eu não faço um serviço desses”. Quando em seguida são apresentadas evidências difíceis de refutar, o trabalhador admite o seu "desenquadramento", mas, ainda assim, continua fingindo submissão: "Rapaz, estou envergonhado, viu. Eu não sei como eu fiz isso". Todavia, o cabo, muitas vezes, sabe que a ação foi proposital, como demonstra o final do relato do entrevistado: "Mas ele fez consciente, sabe? Então a gente vai eliminando."

É válido ainda apreender a reação do cabo ao identificar aqueles que executam sistematicamente o corte fora dos padrões, visto que a dominação em alguns casos também se processa de modo dissimulado. Vejamos o que diz o cabo-recrutador para o "trabalhador desenquadrado" que procura emprego na safra seguinte: "Rapaz, infelizmente tá completo já. Agora, se surgir uma vaga [na turma de cortadores de cana] eu sei o seu endereço e vou buscar [a carteira de trabalho]. Mas não me espere, se aparecer outro, você pega". Assim como os trabalhadores "resistem de modo miúdo" e sem declarar que estão resistindo, o cabo pune, "elimina" sem declarar que está "eliminando". Mas por que ele esconderia o real motivo da não contratação? Para compreendermos essa atitude dissimulada, consideramos importante retomar a análise de Silva: 
Ao exercê-las [funções de supervisão e controle], os feitores [ou cabos] veem-se envolvidos numa rede de relações entre trabalhadores e patrões, que os levam a ser os "recheios de sanduíches", aqueles pressionados tanto de um lado quanto do outro. Pode-se perceber que a situação produzida no bojo destas relações reflete a contradição social existente entre as classes, assim como a resistência dos trabalhadores. Tempo e disciplina no trabalho (Thompson, 1979) são dois pilares básicos, que sustentam os mecanismos de exploração. Aos seus executores cabem as tarefas de transformar estes trabalhadores em força de trabalho. Ao fazê-los, encontram a reação destes. É nesse embate existente nas profundezas dessas relações que vão sendo geradas a consciência e as formas de resistência (SILVA, 1999: 129).

Feitorar implica a aquisição de um saber, que passa pela aprendizagem do processo de trabalho, que pode ser transmitida por outros feitores e pelo (re)conhecimento das pessoas. (Re)conhecer cada um, homem, mulher, mocinha, mulher casada, jovem, homem, adulto, saber de seus problemas é um ato muito importante, é um ato que exige "habilidade" em lidar com as pessoas, A interiorização da dominação, sob o regime do trabalho livre, exige do capital uma organização hierárquica do trabalho que produza e reproduza mecanismos de disciplina. Entretanto, tais mecanismos não são unilaterais. Eles são produzidos no seio das contradições entre as duas forças - a dos patrões e a dos trabalhadores. Rompidos os modelos de dominação pessoal vigentes no momento anterior, a criação das figuras do empreiteiro, que "quebra galhos", da empreiteira, "que sabe dos problemas das mulheres", do feitor, que "não manda o nervosinho para o escritório", não deve ser interpretado apenas vis-à-vis o comando da empresa, como também o processo da aceitação-negação da dominação. (Ibidem: 135)

A análise acima traz à tona elementos fundamentais para compreender a ambiguidade intrínseca à condição de cabo. A primeira diz respeito à posição do cabo no processo produtivo, visto que ele está situado no seio das contradições e conflitos de interesses da relação capital e trabalho. Ele é um assalariado que supervisiona e garante o disciplinamento de outros assalariados. Por isso, o mesmo deve ser dotado de extrema habilidade para lidar com o processo de "aceitação-negação da dominação", deve ser capaz de fazer permanentemente a leitura das relações de poder no interior da turma, não só para cumprir as tarefas básicas de suas atribuições (que essencialmente é de garantir a efetivação dos interesses dos usineiros no processo de trabalho), mas, também porque o seu cargo (e poder) está sempre ameaçado, pois, afinal, ele também é um assalariado e está sujeito ao desemprego.

É por causa desse conjunto de fatores que, em determinadas circunstâncias, o cabo pune como se não estivesse punindo, cobra como se não estivesse cobrando. A dominação não se concretiza apenas pela força (como uma "tropa de choque" pronta para reprimir a qualquer custo quando a ordem está ameaçada), ou pelo "poder da 
caneta" que tem o cabo, ela também é construída nas relações dissimuladas do cotidiano, como demonstra o trecho da entrevista abaixo ${ }^{9}$ :

Pesquisador: Têm casos de trabalhadores que ficam muito tempo descansando?

Entrevistado: Têm.

P: $E$ você tem que chegar junto?

E: Tenho que chegar junto... e saber falar, sabe? [...] Então a gente tem que acordar o trabalhador, chega pertinho [nesse momento o entrevistado bate palmas], o caba [o trabalhador] acorda. "Tava dormindo?" "Eu tava dormindo. Que horas é?" "Tal hora" "Eita, rapaz dormi tanto." Eu digo: "Eu vi o senhor dormindo, eu vou olhar, talvez ele adoeceu," Eu sei que ele não adoeceu. Aí ele diz: "Não, Seu Geraldo, eu estou bom. Mas agora eu vou trabalhar".

A dissimulação está em acordá-lo como se fosse para o seu próprio bem. O sono interrompido para que o trabalho não cesse é apresentado ironicamente em forma de preocupação e cuidado com a saúde. Como para um bom entendedor meia palavra (ou palavra com o sentido invertido) basta, o trabalhador, em seguida, regressa à labuta. Continuar dormindo resultaria em noites ainda mais insones até a (não)contratação na próxima safra. Consideramos necessário realizar essa breve imersão nos procedimentos do cabo porque é impossível compreender a resistência dos trabalhados desvinculando-a do processo de dominação-exploração. Afinal, é nesse pantanoso terreno que a mesma é gestada.

As práticas de resistências cotidianas vão para além do corte fora do padrão, incendiar os canaviais também é um instrumento muito utilizado pelos trabalhadores. Abaixo segue transcrito um trecho de uma entrevista ${ }^{10}$ que revela como são realizadas essas ações:

Entrevistado (E): [...] Esse pessoal que vai estar desempregado vai incendiar a cana, porque hoje já incendeia. Aquelas pessoas que estão lá fora do padrão, que não entra na usina, que está fora da média, ele já incendeia a cana.

Pesquisador (P): Como o senhor sabe que são eles?

$\boldsymbol{E}:$ Porque eles deixam vazar.

P: Mas eles têm interesse que a usina saiba que são eles?

$\boldsymbol{E}:$ Tem não, porque muitas usinas pegam e aí o castigo é grande.

P: E fazem o que [como castigo]?

E: Olha... tem usina que até mata; a [usina] Seresta eu não sei se já fez isso, mas eu já vi sendo pego, ela prendeu, mas não fez o pior.

P: Geralmente, é o pessoal que não está trabalhando que faz isso... esses incêndios...

\footnotetext{
${ }^{9}$ Entrevista realizada em fevereiro de 2011, no município de Teotônio Vilela.

${ }^{10}$ Essa entrevista foi realizada em novembro de 2011 , no município de Teotônio Vilela.
} 
E: Exatamente.

P: Ou não atingiram uma média ou se envolveram numa greve e foram demitidos... O prejuizo é grande para a empresa?

E: Muito grande, porque queima aquela cana que não está no ponto de corte, ainda vai ter três meses ou quatro para ela poder ficar madura.

P: Está aumentando o número de incêndios "criminosos"?

E: Está sim, cada dia está aumentando. Nós temos aí cinco bombeiros trabalhando direto apagando o fogo...

P: Onde ... na [usina] Seresta?

E: Sim, os cinco carros.

P: Tem os vigias do canavial também, não é?

E: Tem os vigias, mas os incêndios são programados.

P:Como?

E: Eles usam vela ou corda...

P: Corda?

E: Olha, uma corda desse tamanho aqui... Eles limpam, colocam fogo aqui e a palha fica aqui, ele passa umas três horas pra poder chegar.

P: É como uma bomba relógio.

E: É e aí eles fogem do local e ficam só esperando... aí ela vai queimando bem devagar.

P: E com a vela, como é?

$\boldsymbol{E}:$ Com a vela funciona mais rápido.

P: Não dá tempo de eles correrem.

$\boldsymbol{E}:$ É, eles pegam uma palha, colocam ela em cima da palha, ai botam fogo e vão embora, mas ela queima rápida, mas às vezes o vento apaga e deixa a prova.

P: Deixa prova como?

E: Fica aquele material da vela.

P: Na [usina] Seresta teve quantos incêndios nessa safra?

E: Tivemos uma média de um por dia.

P: Não acredito! Todo dia tem incêndio!

$\boldsymbol{E}: \dot{E}$, quando não tem num dia, no outro dia tem dois.

O entrevistado também nos informou que os incêndios com o objetivo de causar prejuízos para as usinas é uma prática antiga. No entanto, o relato acima revela que nos últimos anos, essa prática tem ocorrido com mais frequência, chegando atualmente à média de um incêndio por dia nos canaviais da usina Seresta. Se os executores dessas ações forem identificados, o castigo é grande. Segundo o entrevistado, pode-se chegar ao extremo da eliminação física: o assassinato. Por isso, quem incendeia secretamente o canavial, cria mecanismos que possibilitam a fuga muito antes das primeiras labaredas anunciarem a queimada para os fiscais. Esses mecanismos são as velas ou cordas, que, ao serem queimados antes das canas, permitem uma fuga sob menores riscos. Ainda assim, os riscos são altos. Existem equipes de fiscais que fazem rondas nos canaviais e que identificam focos de incêndios do alto de torres. 
A pesquisa de Alves (1991) também aponta incidência de queimadas com caráter semelhante nos canaviais paulistas. Segundo o autor, a ameaça de incêndio teve um importante papel durante a greve de Guariba:

A ameaça de incêndio aos canaviais é, sem dúvida, um dos métodos de intimidação aos usineiros de grande poder, inclusive a presteza do governo e dos patrões em apressarem a realização de negociações [durante a greve de Guariba] pode ser creditada a este artifício. Porque, para que o incêndio seja controlado a tempo, antes de queimar muitos talhões, é necessário mobilizar cortadores para que a cana queimada não se estrague. Estando os trabalhadores em greve, os usineiros não conseguem cortadores e a cana se perde. Se, por outro lado, os usineiros não conseguem mobilizar a turma de controle de incêndios a tempo, este pode se estender para talhões de cana nova, ainda não madura para o corte e calcinar também a soca, tornando muitos talhões improdutivos por, pelo menos dois anos, que é o tempo médio de maturação da cana (Idem, 1991: 136 e 137).

Alves demonstra que a ameaça de queima de canas fora do ponto de maturação pode fortalecer os trabalhadores durante uma greve. Porque, "estando os trabalhadores em greve, os usineiros não conseguem cortadores e a cana se perde". Portanto, as queimadas, nessa circunstância específica, podem ser um eficaz instrumento de luta. Mas os "incêndios sabotadores" não ocorrem apenas durante as greves, em linhas atrás vimos que ele é realizado diariamente em Alagoas. O nosso depoente afirma que os responsáveis por esses incêndios não são os grevistas, mas os trabalhadores canavieiros desempregados. Como interpretar essas ações? Compreendemos esses atos como indignação e revolta, exteriorizadas em forma de chama, e a capacidade de indignar-se é fundamental, pois sem indignação não há resistência.

Mas, ainda assim, cabe indagar: quais são os ganhos reais dos trabalhadores ao promover ações como essas em situações sem greve? É certo que acarreta prejuízos para os usineiros, mas não resulta em elevação dos salários, no fim da exigência de média mínima diária, em abertura de novos postos de trabalho, em abolição do salário por produção, em eliminação dos "eitos gigantes" "... em suma, as degradantes condições de trabalho permanecem intactas. O corte fora do padrão, mesmo sendo uma resistência extremamente limitada, diminui efetivamente o dispêndio de energia do canavieiro para

\footnotetext{
${ }^{11}$ A largura do eito (área de trabalho do cortador de cana) pode variar de acordo com a quantidade de ruas (fileiras) de cana. Enquanto em São Paulo os eitos são compostos por cinco ruas (conquista das históricas greves de Guariba e Leme em meados de 1980), em Alagoas existem atualmente usinas com "eitos gigantes" de até nove ruas. Os eitos mais largos tanto elevam o dispêndio de energia do cortador de cana e rebaixam o valor da sua força de trabalho, quanto ampliam a produtividade industrial e do transporte da cana. Para uma análise dos “eitos gigantes” alagoanos, ver Verçoza (2011).
} 
cortar determinado quantum de cana. Portanto, não traz somente prejuízos para usineiro, existe uma pequena economia de força do trabalhador que reduz minimamente (em um nível quase microscópico) o grau de exploração-dominação. O cerne da questão é: as queimas diárias são armas apontadas para as canas (mercadoria), e não para as relações que produzem a cana e o trabalho degradado. Esse tipo de prejuízo (que sequer arranha a superexploração da força de trabalho) pode ser muito interessante para outros usineiros no bojo da concorrência intercapitalista desse setor agroindustrial ${ }^{12}$, mas, essencialmente pouco contribui para os trabalhadores no conflito entre o capital e o trabalho.

É importante frisar que essas ações individuais dos cortadores, analisadas até aqui, não são as únicas práticas que objetivam combater (ou minimizar) os efeitos da exploração-dominação da força de trabalho nos eitos, pois, nas últimas safras, os trabalhadores canavieiros de Alagoas também realizaram a "atividade desenquadrada" de modo coletivo, por meio de paralisações e greves.

\section{Paralisações e greves nos canaviais}

De acordo com Candido e Malagodi (2010: 11),

durante as safras do corte de cana em 2007/2008 e 2008/2009, o Estado de Alagoas presenciou o surgimento de reações espontâneas dos trabalhadores canavieiros, como o fechamento da BR 101, uma resposta às condições de exploração do trabalho, situação jamais vista na história desse Estado.

Antes de problematizarmos as ações "espontâneas" e como elas se processam, achamos válido investigar uma questão que é anterior: será que mobilizações desse tipo jamais foram vistas na história de Alagoas? Para tentarmos elucidar minimamente essa indagação, é necessário recuar um pouco mais na história.

De acordo com Albuquerque (2009: 102),

Apenas no final da década de 1980, quando a expropriação do trabalhador rural com o esgotamento do sistema de moradia atinge um grau ainda mais avançado e o êxodo alcança patamares até então

\footnotetext{
${ }^{12}$ Por isso, consideramos pertinente a hipótese de que essa prática não seria executada exclusivamente pelos trabalhadores, o incêndio pode ser um dos expedientes nas disputas entre os usineiros.
} 
inéditos, é que se dão as condições objetivas para um maior enfrentamento entre trabalhadores e patrões.

São escassos os relatos de conflitos públicos envolvendo trabalhadores canavieiros durante o período em que as relações de morada eram hegemônicas em Alagoas. Quando Albuquerque afirma que ocorreu "maior enfrentamento" somente no ápice do declínio do sistema de morada, ele refere-se às campanhas salariais promovidas pela FETAG/AL ${ }^{13}$ no final dos anos 1980 , que resultou em paralisação de alguns trabalhadores canavieiros no estado.

Entretanto, seria um grande equívoco superestimar essas ações pioneiras em Alagoas, pois, as campanhas tiveram um alcance extremamente limitado:

Em 1987, quando a Contag e as federações do Nordeste, após vários encontros regionais, optaram pela realização da campanha salarial unificada para a região, acreditando em vantagens econômicas e ganhos políticos, a maioria dos dirigentes sindicais da Fetag-AL ficou contra a realização da campanha, mesmo através da Lei da Greve.

Realizada sob o slogan "Um Milhão de Trabalhadores Unidos na Campanha Salarial", a campanha foi débil na base territorial alagoana, justamente onde já existia a maior concentração de trabalhadores da cana da região [Nordeste], evidenciando o baixo grau de mobilização rural local. Dos 52 sindicatos das áreas canavieiras, apenas 15 atenderam à convocação, de modo que as atividades só foram efetivamente paralisadas em poucos engenhos [fazendas].

Assim, além de tardias e limitadas, as campanhas salariais em Alagoas, como formas de mobilização, estiveram muito longe de corresponder a "eventos espetaculares". O pouco de adesão ao movimento pode ser atribuído muito mais ao próprio grau de exploração e das precárias condições de trabalho do que efetivamente a alguma eficácia da organização sindical (MELLO, 2002: 170 e 171).

Essa mobilização tem um caráter muito distinto das atuais, pois ainda que o real motivo da adesão esteja "muito mais no próprio grau de exploração e precariedade das condições de trabalho do que na eficácia da organização sindical," (Idem) ainda assim, a referida mobilização foi convocada pelos sindicatos, o que sequer ocorre atualmente.

O mais espantoso é que esse período pode ser considerado como sendo o mais "combativo" da história dos sindicatos rurais alagoanos. Nos anos 1990 foram formadas ações de oposição sindical por militantes ligados à CUT e à CPT, no entanto, essas forças políticas não obtiveram êxito. Paulatinamente, o foco desses setores de oposição foi sendo desviado para a luta pela terra. O movimento sindical dos trabalhadores rurais de Alagoas, que desde a sua gestação era avesso às lutas, continua

\footnotetext{
${ }^{13}$ FETAG -AL é a abreviatura da Federação dos Trabalhadores e Trabalhadoras na Agricultura do Estado de Alagoas.
} 
sendo "controlado, em grande parte, por líderes comprometidos com o patronato local e as elites políticas conservadoras”. (ALBUQUERQUE, 2009: 103).

A avaliação de Mello (2002: 168) sobre o papel da FETAG segue a mesma linha da leitura de Albuquerque:

A rigor, a Fetag-AL nem sequer incorporou efetivamente a luta pelos "direitos", ficando em boa medida ausente do cumprimento das conquistas dos trabalhadores em troca de benefícios em favor das trajetórias pessoais de seus dirigentes no jogo político local.

Realizamos uma entrevista ${ }^{14}$ com um presidente de sindicato dos trabalhadores rurais que está na diretoria da entidade desde o final dos anos 1980. Abaixo segue o relato das mudanças na prática sindical ao longo de sua carreira como dirigente da entidade:

Entrevistado: Hoje a gente se reúne em Maceió. A gente passa o período todinho aqui na região, e no final a gente vai pra Maceió pra formar a minuta, pra discutir os direitos... tudo. E lá tem... quando eu comecei no movimento mesmo, ia negociar e era uma confusão tão grande lá no MT [Ministério do Trabalho]. A gente levava sanfona, apito, triângulo, era uma zoeira pra poder a gente chegar em algum acordo, né?! Aí, com o tempo foi mudando. O negociador, um "cara" mais prestativo lá ...muitas vezes a gente negocia na própria sede da gente lá em Maceió, na FETAG. O que antigamente não queria ver de jeito nenhum o sindicato. Agora os patrões vão lá e negociam lá. A última agora foi lá no sindicato do açúcar [sindicato dos usineiros].

Essas transformações na forma de negociar nos foram relatadas como se fizessem parte de um processo natural, sendo, inclusive, consideradas verdadeiras conquistas, enquanto, na realidade, mostram a cooptação dos sindicatos pelos usineiros. Afirmamos isso, pois, as negociações mencionadas acima não dizem respeito ao cumprimento da legislação trabalhista, muito menos estão sendo negociadas reivindicações de uma greve. Trata-se da Convenção Coletiva de Trabalho, que não é divulgada entre os trabalhadores e que tem pontos que são descumpridos ${ }^{15}$. Para Mello (2002: 169 e 170), no fundo, os termos do "acordo" pouco interessam, uma vez que também está "implícito o não cumprimento, tanto pela inexistência de pressão dos dirigentes como pelo desconhecimento da base".

\footnotetext{
${ }^{14}$ Realizamos essa entrevista em 24 de fevereiro de 2011, no município de Teotônio Vilela.

${ }^{15}$ Dentre os pontos descumpridos, podemos destacar, como exemplo, as recorrentes fraudes na medição e pesagem das canas cortadas (que foi uma reclamação constante dos trabalhadores entrevistados) e 0 número de ruas que compõe o eito. Segundo a Convenção Coletiva de Trabalho dos canavieiros de Alagoas, os eitos deveriam ter no máximo sete ruas (que já é aviltante para o trabalhador), no entanto existem usinas que estabelecem eitos com nove ruas e permanecem impunes!
} 
Essa breve incursão no histórico das (in)ações dos Sindicatos de Trabalhadores Rurais de Alagoas, demonstra que, se as greves dependessem da iniciativa dessas entidades, elas não aconteceriam. Desse modo, não é difícil compreender por que as recentes ondas de paralisações e greves ocorrem à revelia desses sindicatos. Quando os sindicatos de trabalhadores rurais tentam dirigir a greve que já foi deflagrada, muitas vezes, os trabalhadores reagem de modo enérgico e indignado, podendo chegar ao ponto de o carro do sindicato ser apedrejado. ${ }^{16}$ Isso explicita cristalinamente o grau de descrédito e ilegitimidade dessas entidades que, em tese, deveriam representar os trabalhadores rurais. Seguem abaixo depoimentos de dois trabalhadores que participaram da greve da usina Seresta ${ }^{17}$ :

Pesquisador: Quando o sindicato foi lá na greve, o senhor estava presente?

Entrevistado: Nós estávamos todos lá. Chegaram... mas os sertanejos não quiseram conversa com eles não. Porque eles não acertam nada também. Se eles fossem conversar, eles queriam era só enganar. Aí veio um de São Miguel. Conversaram um pouco com eles, mas eles não quiseram acerto com eles em nada.

Pesquisador (P): E o sindicato estava junto lá [na greve]?

Entrevistado (E): Estava lá. Eles ficaram lá dizendo que a gente tinha direito, mas que não ia ser dado pela empresa!

P: Então eles desmobilizaram a greve?

E: Não, porque disseram que ali não tinha jeito, que ia ser difícil, eles tinham medo do que podia acontecer.

$\mathrm{O}$ primeiro depoimento revela que o trabalhador entrevistado não considera $\mathrm{o}$ sindicato como aliado, pelo contrário, "eles queriam só enganar". O relato do segundo entrevistado confirma que foi essa a postura dos sindicalistas de Teotônio Vilela, de forma que, quando eles afirmaram que "nada ia ser dado pela empresa", estavam sugerindo que a greve não teria razão de existir, que ela seria puramente desgaste para os trabalhadores.

Conforme apontaram Candido e Malagodi (2010), nas safras de 2007-2008 e 2008-2009 também ocorreu um expressivo número de paralisações. As reivindicações foram diversas, destacando-se: contra a fraude no sistema de pesagem da cana; pela redução da média diária mínima de toneladas de cana cortadas; pelo aumento do preço

\footnotetext{
${ }^{16}$ Conforme o relato oral de um dirigente da Comissão Pastoral da Terra, que presenciou essa cena durante uma paralisação de trabalhadores canavieiros em uma rodovia alagoana.

${ }^{17}$ A referida greve ocorreu em janeiro de 2011. As entrevistas foram realizadas em fevereiro de 2011.
} 
da tonelada; contra o atraso do pagamento de salário, dentre outras (QUEIROZ, 2011: 74 e 75$)$.

$\mathrm{Na}$ safra 2010-2011, as greves e paralisações dos trabalhadores canavieiros foram ainda mais intensas, sendo que a principal reivindicação desse período foi pelo fim do contrato safrista (ou por tempo determinado). Essa forma flexível de contrato, que é prevista em lei, não permite o acesso do trabalhador ao aviso prévio, a multa rescisória de $40 \%$ e ao seguro desemprego. Com isso, tanto os usineiros pagam menos tributos, quanto o Ministério do Trabalho economiza recursos que seriam destinados para o seguro desemprego. Das 24 usinas de Alagoas, 16 adotaram o contrato safrista naquela safra ${ }^{18}$. Segundo um dirigente da FETAG-AL, ocorreram mais de 20 greves e paralisações durante a moagem de 2010-2011, sendo que 13 dessas bloquearam rodovias.

Em fevereiro de 2011 pudemos conversar com trabalhadores da usina Seresta e Guaxuma $^{19}$, em ambas, os cortadores de cana haviam entrado em greve nesta safra. Na primeira empresa a greve durou dois $\operatorname{dias}^{20}$; na segunda, foram cinco dias ${ }^{21}$. A principal reivindicação das duas greves foi pelo fim do contrato safrista. As duas ações também ocorreram à revelia dos sindicatos, apesar de os sindicatos tentarem dirigir a greve após sua deflagração, como demonstra o depoimento do sindicalista sobre a greve na Seresta $^{22}$ :

Pesquisador (P): Mas, vocês dialogaram com os trabalhadores [durante o bloqueio da BR]?

Entrevistado (E): A gente dialogou, mas com os "caras" não tem conversa, não. Teve tenente da polícia lá...com educação, tentando de todo jeito que podiam e não conseguiram.

P: $E$ se procurasse conversar com alguma liderança, um representante, não tinha não?

E: Não tinha porque...tinha um cara lá que tava liderando, mas era negócio de segundos, lideravam: "vamos fazer? - Vamos" quando partia lá dos fundos e diziam que "não vai", ai desmanchava tudo. Foi o dia todo assim nessa "peleja".

P: Não tinha como encontrar quem tava dirigindo a greve?

$\boldsymbol{E}:$ Não, ali não teve não.

P: Não havia identificação?

E: Não, nem o pessoal do setor de negociação...não tinha não.

P: Por isso que demora tanto [para desbloquear a estrada]?

E: Por isso que demora!

\footnotetext{
${ }^{18}$ Essas informações foram colhidas no site da FETAG-AL: http://www.fetagal.org.br/

${ }^{19}$ A usina Guaxuma fica localizada no município de Coruripe, que faz fronteira com Teotônio Vilela.

${ }^{20}$ Durante os dias 6 e 7 de janeiro de 2011.

${ }^{21}$ Entre os dias 8 e 12 de fevereiro de 2011.

${ }^{22}$ Entrevista realizada em fevereiro de 2011, no município de Teotônio Vilela.
} 
P: Mas é uma forma deles se prevenirem pra não ficar marcado...

$\boldsymbol{E}: \dot{E}$, exatamente!

Portanto, a "ausência" de líderes públicos não significa necessariamente ausência de lideranças entre os trabalhadores canavieiros. Em nossas entrevistas com os cortadores de cana, foi comum escutar o termo "os cabeças", que seriam aqueles com maior capacidade de persuasão e disposição para enfrentar os usineiros, deixando clara a existência de líderes. Porém, a liderança exercida de modo oculto foi um meio encontrado para tentar minimizar a repressão, tanto da greve como um todo, quanto sobre os líderes. Por isso, os trabalhadores se organizavam de um modo que aparentasse desorganização. A aparente falta de tática para negociar também era uma tática:

Pesquisador (P): Como foi que o pessoal resolveu parar os trabalhos?

Entrevistado (E): Nós chegamos lá no serviço e começamos a trabalhar. Ai chegou um trabalhador mesmo de moto, avisando que era para parar todo mundo. Os "caras" vinham doido de pedra para arrebentar tudo. Ai pronto: nós "paramos" tudo.

P: Alguém tentou continuar trabalhando?

E: Ninguém não. Mas eu sei que ajuntaram os carros [ônibus] tudinho num canto só e fomos "s'imbora".

P: Todos os ônibus?

E: Desceram todos para usina.

P: Foram para a porta da Seresta?

E: Foi. Os carros [ônibus] pararam no pátio da usina. Aí... eu pensei que eles iam fechar a usina mesmo lá, mas não, voltaram para pista. Aonde tinha pau... tudo eles arrocharam no meio da pista e tocaram fogo. Só se via a fumaça. Pararam tudo.

P: Isso foi mais ou menos em que horário?

E: Foi logo de manhã. Por volta dumas dez horas.

P: E chegou gente da usina para negociar logo?

E: Os "caba" [pessoal] da usina nem perto chegou.

P: E a polícia Federal chegou que horas?

E: Primeiro chegou a polícia daqui. Os caras botaram logo para lavrar [correr]: "Ninguém quer conversa com vocês não: desaba". Ai eles subiram a ladeira de novo. Depois chegou o BOPE. O BOPE ficou só de longe, viu que o povo tinha razão, não é? Ficou tudo de longe, nem perto chegou.

P: Vocês estavam com as ferramentas de trabalho, facão...

E: É... A maioria lá estava tudo de facão.

P: Ninguém queria nem chegar perto. E o BOPE ficou só olhando?

E: Ficaram lá só de fora olhando. Depois chegou a Federal, tentou conversar com os caras lá, mas os caras não quiseram conversa com eles também.

P: Queriam negociar direto com o gerente da usina?

E: Com o gerente mesmo... com o gerente geral, não é? Mas ele não foi lá. Eu sei que quando foi na base dumas quatro horas da tarde eu vim embora. Ai eles ainda ficaram pra lá. Saiu depois um carro com um bocado de gente pra Maceió, da turma, da turma mesmo geral que trabalha na Seresta. Isso foi de noite, saíram já de noite. Eu sei que 
passou a noite por lá. Quando foi no outro dia ninguém foi trabalhar. Ninguém trabalhou.

A partir da narrativa acima, podemos inferir que a tática de não negociar com a polícia não decorre meramente da necessidade de proteger "os cabeças", mas, sobretudo, pela compreensão de que a polícia não seria capaz de atender as reivindicações. O depoimento também revela que, em decorrência da dispersão das turmas pelas diferentes áreas do canavial, a articulação para iniciar a greve teve que ser feita mediante a ação de trabalhadores motorizados. Todas as turmas de cortadores de cana da Seresta aderiram ao movimento, diferentemente da greve da usina Guaxuma, que só conseguiu unificar todas as turmas apenas durante o segundo dia de greve $^{23}$, como indica o depoimento abaixo:

Pesquisador (P): O pessoal da cidade de Teotônio, os "da rua" [os do lugar], como costumam ser chamados, foram para a greve no dia do fechamento [da rodovia federal]?

Entrevistado (E): Foram no outro dia [no segundo dia da greve deflagrada pelos sertanejos na usina Guaxuma]. O pessoal se reuniu, entraram quarenta e cinco no ônibus e pararam doze ônibus [de trabalhadores 'da rua'], aí levaram os doze ônibus para porta da usina. [...]

P: E eles [os 'da rua'] participaram depois desse dia?

E: Não. Eles só pararam um dia. Aí depois mandaram falar para gente: que eles não poderiam parar mais, e que muitos pagavam aluguel, mas estavam em acordo com a gente. Se a gente voltasse a trabalhar eles davam o maior apoio, mas se nós não quiséssemos, eles davam mais ainda que era para a gerência sentir o que estava fazendo. Aí eu retornei a ligação para um deles, eu falei: "É, vocês tão no direito de vocês e nós estamos no nosso. Só que é aquela história, se vocês parassem dois dias facilitava melhor para gente."

P: Porque era todo mundo junto...

E: Era, "mas já que vocês não querem... sigam em frente que nós vamos seguir em frente também".

Essa desarticulação dos trabalhadores canavieiros da Guaxuma enfraqueceu significativamente a greve, pois, pelo trabalho "dos da rua" (os do lugar), a usina continuou moendo cana. Esse é um dos fatores que explicam a derrota (do ponto de

\footnotetext{
${ }^{23}$ Dentre os fatores que dificultaram a unidade na greve da usina Guaxuma, está o critério de formação das turmas, que separa os trabalhadores "da rua" (os do lugar) dos sertanejos (migrantes do Sertão alagoano e pernambucano), e isso faz com que eles cortem a cana em turmas e em locais distintos. Ademais, a esmagadora maioria dos sertanejos que trabalha na Guaxuma reside em um alojamento afastado da área urbana. Sendo assim, o contato dos sertanejos com "os da rua" é muito escasso.

$\mathrm{Na}$ Seresta, essa mesma situação assume contornos diferentes, visto que os sertanejos e "os da rua" podem trabalhar numa mesma turma. Isso ocorre tanto porque o número de migrantes na Seresta é pequeno, quanto pela ausência de alojamento nessa empresa.
} 
vista mais imediato) da greve da Guaxuma e a vitória dos canavieiros na Seresta ${ }^{24}$. Na primeira, 22 trabalhadores considerados como "os cabeças" foram demitidos, a demissão foi marcada pela intimidação de policiais que obrigavam os trabalhadores dispensados a se retirarem do alojamento (propriedade privada da usina), não foram dadas garantias algumas em relação ao fim do contrato safrista. Na segunda greve, os trabalhadores conseguiram alterar a forma de contrato de trabalho no segundo dia de paralisação.

Ainda é interessante nos determos brevemente na greve da Guaxuma, pois ela vai de encontro (em sentido contrário) ao que diz parte da literatura sobre o trabalho de migrantes nos canaviais alagoanos. Padrão (1997: 140), ao analisar a reestruturação produtiva numa das usinas localizadas no município de Coruripe, afirma que os trabalhadores sertanejos são vistos pela gerência da empresa como "os mais produtivos e disciplinados". No mesmo sentido, Mello (2002: 175 e 176) afirma que

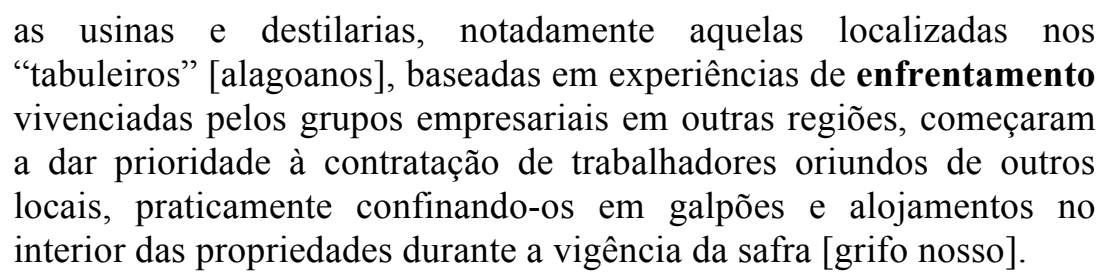

Francisco Alves também sugere que o interesse da agroindústria canavieira paulista em empregar força de trabalho migrante, do Nordeste especialmente, está relacionado, dentre outros fatores, ao conjunto de pressões que os fazem ser considerados mais "tranquilos, que não criam confusão, de trato fácil "(ALVES, 2007: 46). Mesmo que Alves esteja analisando um caso de migração regional, que difere da migração intraestadual dos sertanejos que trabalham na Guaxuma e na Seresta, é válido sublinhar a existência de uma linha de argumentação que explica a preferência das usinas pelos trabalhadores migrantes, não somente por sua suposta maior produtividade, mas, também, por sua maior docilidade à submissão, à exploração-dominação, quando comparados aos trabalhadores locais.

A mesma representação do migrante sertanejo como trabalhador dócil e submisso, de trato fácil, reaparece na representação simbólica e no discurso da gerência de usinas e de trabalhadores canavieiros (os do lugar) em Pernambuco:

\footnotetext{
${ }^{24}$ Outro fator que pode ter contribuído para a vitória da greve da Seresta, diz respeito ao fato de Teotônio Vilela Filho, atual governador de Alagoas, ser um dos donos dessa usina. O prolongamento da greve poderia ampliar ainda mais o seu desgaste político.
} 
Os pernambucanos enfatizam que os paraibanos [migrantes do sertão] tendem a aceitar as condições impostas pela usina, porque procedem de lugares distantes, vivem em situação de miséria e, naturalmente, precisam manter seus empregos (MENEZES, 2002: 187).

Todavia, Menezes adota uma perspectiva de questionamento dessa leitura do sertanejo como trabalhador dócil (que a autora chama de "discurso dominante") por meio da análise das práticas cotidianas de resistência e das greves. $\mathrm{Na}$ análise das formas de resistências cotidianas, Menezes (Idem) demonstra que esses trabalhadores constroem diversas formas de microrresistência, porém, quanto às greves analisadas por Menezes, os canavieiros migrantes do sertão paraibano em momento algum aparecem como protagonistas. Quando participam, é sempre de forma subalterna. Mesmo quando foram o estopim de uma greve (por não aceitarem ser transportados em caminhões) ${ }^{25}$, esta foi dirigida desde o início pelo sindicato local.

A greve da usina Guaxuma parece-nos paradigmática, justamente, por inverter o discurso que Menezes chamou de "dominante", visto que os migrantes sertanejos foram muito mais combativos do que os trabalhadores "da rua". Isso demonstra que, mesmo submetidos a condições objetivas extremamente adversas, os sertanejos são capazes de resistir por meio de um enfrentamento público e coletivo.

Consideramos que seria infrutífero investigar as causas mais profundas do protagonismo dos sertanejos na greve da Guaxuma, pois, como nos alerta Rosa de Luxemburgo (2011: 307):

O elemento da espontaneidade desempenha, como vimos, um grande papel na greve de massas, sem exceção, seja como elemento propulsor ou como elemento repressor. Mas isso não decorre de, na Rússia, a social-democracia ainda ser jovem ou fraca, mas porque para cada ato isolado da luta concorrem incalculáveis elementos econômicos, políticos e sociais, gerais e locais, materiais e psíquicos, de modo que nenhum ato pode ser determinado e realizado como um exemplo aritmético.

Quando Luxemburgo utiliza termos como "espontaneidade" e "lutas espontâneas", ela não está se referindo a ações desorganizadas ou impensadas, mas, sim, a lutas de caráter público que não foram produzidas por organizações políticas já estruturadas, como sindicatos e partidos ${ }^{26}$. Para Luxemburgo (Idem: 318), o

\footnotetext{
${ }^{25}$ A referida greve ocorreu em dezembro de 1992, no município de Igarassu/PE (MENEZES. 2002: 203).

${ }^{26}$ Rosa de Luxemburgo escreveu Greve de massas, partido e sindicatos em 1906; levando em consideração esse contexto histórico, a autora considera como organizações políticas do proletariado os sindicatos e os partidos. Na conjuntura atual, podemos incluir os movimentos sociais, como os do sem
} 
“entendimento rígido, mecânico-burocrático, só admite a luta como produto da organização que atinja certa força. O desenvolvimento dialético vivo leva, ao contrário, à organização como produto da luta." Com isso, Luxemburgo destaca que o elemento espontâneo - espontaneidade - desempenha um papel fundamental nos rumos da luta de classes. Essa formulação guarda semelhanças com o conceito thompsiano de experiência (THOMPSON, 1981), pois para ambos a luta de classes não é produzida somente pela ação dos partidos e sindicatos.

No tocante à greve espontânea da Guaxuma, ainda que aparentemente ela tenha sido derrotada, o saldo geral das greves da safra 2010-2011 foi positivo, visto que na safra 2011-2012 apenas a usina Coruripe continua trabalhando com o contrato safrista ${ }^{27}$. Mas, mesmo que essas conquistas tenham sido frutos de árduas e perigosas lutas, é preciso reconhecer os seus limites, pois, devemos estar cientes de que as formas de resistência analisadas nesse artigo são lutas individuais e coletivas "contra os efeitos, mas, não contra a causa desses efeitos" (MARX, 1982: 184).

Todavia, também não podemos nos esquecer de que a condição sine qua non para que sejam realizadas lutas contra as causas da exploração-dominação, é estar vivo. E é exatamente pela sobrevivência que os trabalhadores canavieiros alagoanos lutam atualmente. E nessa luta os laços de solidariedade de classe são fortalecidos, as máscaras dos inimigos tornam-se transparentes, as pequenas conquistas vão demonstrando que é possível sonhar mais alto.

\section{A máquina movente para demover os movimentos de paralisação}

Após as greves e paralisações da safra 2010-2011, o espectro do fim do corte manual da cana foi fortalecido. O informativo do sindicato dos usineiros de Alagoas anunciou que:

Com o avanço do processo de mecanização no campo, o setor sucroenergético alagoano segue a tendência e amplia o número de máquinas destinadas à colheita da cana. Nesta safra [2011-2012], mais de 20 colhedoras foram adquiridas. Com configurações específicas para operar na topografia existente em Alagoas, cada equipamento

terra, sem teto, desempregados, indignados, piqueteiros, zapatistas, dentre outros com teor semelhante, como organizações políticas dos trabalhadores.

${ }^{27}$ De acordo com informações coletadas no site da FETAG-AL: http://www.fetagal.org.br 
substitui, em média, 80 homens necessários para a colheita manual. "A mecanização é uma tendência e não tem como ser evitada. $O$ mercado é competitivo. Na região sul [de Alagoas] ela é favorável por conta da topografia dos tabuleiros e pode ultrapassar mais de $50 \%$ da colheita nas próximas safras", declarou o gerente administrativo da usina Sinimbu, Silvano Alves, informando que, no ciclo atual, a unidade já conta com sete máquinas na colheita e uma adaptada para o plantio. [...] Segundo o Sindaçúcar-AL, Alagoas conta atualmente com $20 \%$ de sua área de cana colhida por máquinas. (INFORMATIVO DO SINDAÇÚCAR-AL, 2011, grifos nossos).

Nesse contexto, cortadores de cana, bituqueiros, cabos e operadores de carregadeira temem o fim dos seus postos de trabalho. Abaixo, seguem trechos da entrevista realizada com um cabo da usina Seresta ${ }^{28}$ :

Entrevistado: Eles [os sindicalistas] falaram que no ano passado tinha oitenta mil trabalhadores no estado de Alagoas cortando cana; por causa delas [das máquinas] esse ano só tem sessenta mil, e eles têm uma previsão para 2015, de estar com 100 máquinas em Alagoas. [...] eles acham que em 2015 só haverá vinte mil pessoas no corte da cana.

A Federação dos Trabalhadores e Trabalhadoras na Agricultura do Estado de Alagoas (FETAG-AL) divulgou a sua estratégia "combativa":

Este ano, o setor canavieiro foi responsável por cerca de $60 \mathrm{mil}$ contratações em Alagoas. De acordo com o presidente da Fetag/AL, Genivaldo Oliveira, houve uma diminuição no número de trabalhadores contratados no Litoral Sul do Estado devido à mecanização que substituiu o trabalho humano. Entretanto, segundo ele, houve uma compensação no Litoral Norte, por causa do aumento da safra na região. "A tendência, nos próximos dez anos, é reduzir o número de trabalhadores no setor. Por isso, o governo precisa de soluções para evitar um grande número de desempregados. Já estamos com projetos pensando alguns programas que vão servir como assistência", afirmou Genivaldo (FETAG, 2011, grifos nossos) ${ }^{29}$.

Algumas pesquisas acadêmicas já realizam projeções dos impactos do processo de mecanização da colheita da cana em Alagoas $^{30}$ :

[...] podemos perceber que o setor sucroalcooleiro brasileiro já vem se organizando de diversas formas para que toda a cana plantada seja colhida por meio de máquinas colheitadeiras. A mecanização invade o setor sucroalcooleiro do país e, em virtude da competitividade, não poderia ser diferente em Alagoas (BERTOLDO et al., 2011: 148).

\footnotetext{
${ }^{28}$ Fragmentos da entrevista realizada em 29 de outubro de 2011, no município de Teotônio Vilela.

${ }^{29}$ Informações coletadas no site da FETAG-AL: http://www.fetagal.org.br . Acesso em: jan. de 2012.

30 Como a dissertação de Santos (2011), que objetiva traçar quais seriam os impactos de uma mecanização massiva na colheita da cana, em Alagoas.
} 
É de extrema relevância que a sociedade passe a se perguntar sobre qual será o destino desses milhões de trabalhadores rurais cortadores de cana espalhados pelas usinas brasileiras, cujo perfil indica um nível de escolarização muito baixo ou ausente, que não lhes permite migrar para outras atividades, inclusive no próprio setor canavieiro. Isso se agrava, sobretudo, num Estado como Alagoas, cuja geração de empregos é insuficiente para suprir a necessidade de sua população. Os problemas sociais derivados da dispensa dos trabalhadores em razão da mecanização da produção serão de proporções alarmantes, traduzidos principalmente no alto grau de pobreza e violência (Idem, 2011: 153).

No entanto, julgamos que antes de investigarmos os efeitos da mecanização nos canaviais alagoanos, é imprescindível que busquemos compreender por que algumas usinas de Alagoas estão adotando a colheita mecanizada. Comecemos a partir da linha de raciocínio das citações acima: seria porque usinas localizadas em São Paulo já a adotam intensamente ${ }^{31} \mathrm{e}$, sendo assim, aquelas que ainda não a incorporaram perdem competitividade? Quando o uso de maquinário barateia o custo de produção em usinas de determinadas localidades, fatalmente, as usinas de outras regiões terão que adotá-lo? Para elucidar essas indagações, consideramos necessário retomar passagens da análise de Marx (1985: 21 e 22) sobre a Transferência de valor da maquinaria ao produto:

Considerada exclusivamente como meio de baratear o produto, o limite para o uso da maquinaria está em que sua própria produção custe menos trabalho do que o trabalho que sua aplicação substitui. Para o capital, no entanto, esse limite se expressa de modo mais estreito. Como ele não paga o trabalho aplicado, mas, o valor da força de trabalho aplicada, o uso da máquina lhe é delimitada pela diferença entre o valor da máquina e o valor da força de trabalho substituída por ela. Como a divisão da jornada de trabalho em trabalho necessário e mais-trabalho é diferente em diferentes países, como no mesmo país em diferentes períodos ou no mesmo período em diferentes ramos de atividades; como, além disso, o verdadeiro salário do trabalhador ora cai abaixo do valor da própria força de trabalho, ora se eleva acima dele, a diferença entre o preço da maquinaria e o preço da força de trabalho a ser substituída por ela pode variar muito [...] Por isso, são inventadas hoje, na Inglaterra, máquinas que só são empregadas na América do Norte [...] A própria máquina, em países há mais tempo desenvolvidos, produz, por sua aplicação em alguns ramos de atividade tal excesso de trabalho (redundancy of labour, diz Ricardo), em outros ramos, que aí a queda do salário abaixo do valor da força de trabalho impede o uso da maquinaria e torna-o supérfluo, freqüentemente impossível do ponto de vista do capital, cujo lucro surge de qualquer modo da diminuição não do trabalho aplicado, mas do trabalho pago. [...] Os ianques inventaram máquinas britadoras. Os

\footnotetext{
${ }^{31}$ Atualmente, contando com $60 \%$ da área plantada já mecanizada (segundo estimativas da União da Indústria da Cana-de-Açúcar - UNICA - ).
} 
ingleses não as utilizam porque o "miserável" (wretch é o termo da Economia Política inglesa para trabalhador agrícola) que faz esse trabalho recebe como paga parte tão diminuta de seu trabalho que a maquinaria encareceria a produção para o capitalista.

Dessa longa explanação, podemos concluir que só interessa ao capitalista empregar a maquinaria quando o valor da máquina é mais barato do que o valor da força de trabalho substituída por ela (lembrando que a máquina não cria valor, ela somente o transfere). Como o valor da força de trabalho não é o mesmo em distintos países, ou em diferentes regiões de um mesmo país ${ }^{32}$, é possível, por exemplo, o capital agroindustrial canavieiro situado em São Paulo baratear o custo da produção mediante o uso de máquinas colheitadeiras sem acarretar, fatalmente, necessidade de incorporação de máquinas colheitadeiras em canaviais de Alagoas. Isto porque, se em Alagoas o valor da força de trabalho a ser substituída pela colheitadeira for mais baixo do que o valor da máquina, a maior competitividade da agroindústria canavieira alagoana se realizaria justamente por meio do corte manual da cana. Sendo assim, o usineiro não teria interesse em mecanizar a colheita em solo alagoano. Portanto, a tese de que a "mecanização invade o setor sucroalcooleiro do país e, em virtude da competitividade, não poderia ser diferente em Alagoas", carece de mediações. A decisão do capitalista em mecanizar não decorre de imitações intuitivas, ela é baseada, sobretudo (mas não somente), na análise do custo da produção.

Todavia, não devemos concluir que "a queda do salário abaixo do valor da força de trabalho" necessariamente "impede o uso da maquinaria e torna-o supérfluo", visto que, em determinadas circunstâncias, a maquinaria pode ser utilizada para evitar altas no valor da força de trabalho:

A maquinaria não atua, no entanto, apenas como concorrente mais poderoso, sempre pronto para tornar o trabalho assalariado "supérfluo". Aberta e tendencialmente, o capital a proclama e maneja como uma potência hostil ao trabalho. Ela se torna a arma mais poderosa para reprimir as periódicas revoltas operárias, greves etc., contra a autocracia do capital. Segundo Gaskell, a máquina a vapor foi desde o início um antagonista da "força humana" que capacitou os capitalistas a esmagar as crescentes exigências dos trabalhadores, que ameaçavam levar à crise o nascente sistema fabril. Poder-se-ia escrever toda uma história dos inventos que, a partir de 1830, surgiram apenas como armas do capital contra motins dos operários (MARX, 1985: 51 e 52, grifos nossos).

32 Lembrando que o valor da força de trabalho é medido basicamente "pelos valores das mercadorias necessárias à sua manutenção" (MARX, 1982: 165). Como vimos em linhas atrás, esse valor oscila no decorrer da incessante luta entre o capital e o trabalho. 
Essa passagem indica que a maquinaria pode ser utilizada, não somente como instrumento para baratear imediatamente o custo da produção, nem tampouco como simples meio de gerar mais-valia relativa, pois, mesmo que o valor da máquina seja superior ao da força de trabalho que ela substitui, ainda assim, ela pode ser empregada para frear greves e movimentos que poderiam resultar em elevação dos salários, mudanças nas relações de trabalho e etc. É importante compreender por que Marx adotou o verbo "proclamar" na frase: "o capital a proclama e maneja como uma potência hostil ao trabalho" (Idem). Ele poderia ter-se limitado a dizer que o capital maneja a maquinaria como potência hostil ao trabalho, mas não seria tão preciso, visto que, em uma conjuntura de ascensão das greves, não basta incorporar algumas máquinas, é preciso ainda "anunciar em voz alta" que as máquinas irão "substituir um número $\mathbf{x}$ de trabalhadores"; o capital precisa bradar que "a mecanização é um caminho inevitável" para que as máquinas cumpram eficazmente a sua tarefa repressiva, que está ancorada no efetivo medo do desemprego.

No que tange ao uso de colheitadeiras nos canaviais paulistas, segundo Alves (1991: 84), foi somente após o ciclo de greves, iniciado em Guariba (1984), que a mecanização se tornou mais intensa:

Através de entrevistas, realizadas com uma série de usineiros da Região de Ribeirão Preto, ficou claro que a decisão de mecanizar o corte da cana não foi tomada unicamente com base na viabilidade econômica da mecanização, frente ao corte manual, numa comparação entre o custo de operação da máquina e tempo de amortização de investimento versus custo de mão-de-obra dos cortadores de cana. $\mathrm{O}$ que foi revelado, textualmente, nessas entrevistas, é que a mecanização do corte foi incentivada, a partir de 1984, devido às greves anuais de trabalhadores assalariados rurais da região que, ao paralisarem o corte, paralisavam também as usinas. Nestas condições, a mecanização do corte da cana era, segundo os usineiros, a forma de adquirirem maior poder de barganha para negociar a pauta de reivindicações dos trabalhadores, sem as unidades de produção paralisadas. Com a mecanização do corte, as usinas podem continuar funcionando, mesmo com os cortadores de cana em greve, moendo a cana cortada pelas máquinas.

A citação acima evidencia claramente como a colheita mecanizada tende a enfraquecer as greves dos cortadores de cana, visto que a máquina não impõe somente o medo do desemprego, ela ainda possibilita que a produção de açúcar e álcool não seja paralisada durante uma greve dos cortadores. Portanto, existe também uma lógica política subjacente ao processo de emprego mais intensivo de colheitadeiras nos 
canaviais paulistas ${ }^{33}$, pois, pela lógica estritamente econômica, as máquinas ainda acarretam elevação dos custos de produção:

Do lado dos usineiros, a supressão da queima através da mecanização, além de envolver novos custos, ainda não está tecnicamente resolvida. Existem problemas, tais como a ainda reduzida longevidade do canavial, quando submetido ao corte mecânico, a ocorrência de novas pragas e o não aproveitamento da palha para geração de energia elétrica. Esses problemas técnicos levam à elevação de custos de produção, que comparativamente à forma de exploração da força de trabalho ora existente, com elevada produtividade do trabalho e baixa remuneração, leva a que um conjunto de usineiros e fornecedores prefiram o corte manual (ALVES, 2009: 165).

No tocante ao emprego do corte mecanizado em Alagoas, segundo Mello (2002: 108), a primeira empresa a adotá-lo foi a usina Triunfo, em $1997^{34}$. Em 2002, cinco usinas do estado utilizavam colheitadeiras. Naquele ano, a estimativa era que, em uma década (até 2012), o maquinário substituiria cerca de " $80 \%$ dos trabalhadores empregados nos canaviais alagoanos" (idem). Passados os dez anos, esses números não se materializaram. Mas, novas estimativas que partem do pressuposto da inevitabilidade da mecanização em massa, em curto prazo, continuam sendo proclamadas. Essas "previsões" desconsideram não somente a análise do custo da força de trabalho e dos rumos da luta de classes, elas ignoram, inclusive, os atuais limites técnicos das máquinas colheitadeiras.

Entrevistamos um cabo da usina Seresta que apontou alguns desses limites ${ }^{35}$ :

Entrevistado: Então, no momento, essas máquinas não são benéficas para o trabalhador, a gente já ouviu eles conversando... no futuro, muitas pessoas ficarão desempregadas. Para a usina, não sei se eles fizeram cálculos, mas só pelas duas [colheitadeiras] que trabalharam o ano passado a gente já viu o prejuízo. Nós replantamos três lotes, se a terra estiver seca elas cortam bem, se a terra estiver molhada ela estraga a cana, porque os facões dela não são tão amolados quanto o facão que o trabalhador amola,... então, elas cortam, mas também arrancam. Então, o futuro vai ser ruim para o trabalhador, porque vai ter menos emprego, para a empresa vai haver as suas economias de um lado, mas também os seus prejuízos de outro.

\footnotetext{
${ }^{33}$ Para Alves (2009: 160), a mobilização de um amplo conjunto de organizações da sociedade civil pelo fim da queima dos canaviais, é também um fator que pressiona pelo uso mais intenso das colheitadeiras em São Paulo.

${ }^{34}$ Como escrevemos em linhas atrás, diferentemente de São Paulo, nos anos 1980 em Alagoas não existiu um forte acirramento da luta de classes nos canaviais. Ademais, não houve (como ainda não há) mobilização expressiva pelo fỉm das queimadas dos canaviais e nem uma legislação específica que regulamente a sua eliminação (SANTOS, 2011).

${ }^{35}$ Entrevista realizada em 29 de outubro de 2011, no município de Teotônio Vilela.
} 
Segundo um operador de carregadeira da usina Sinimbu ${ }^{36}$, no início da safra 2011-2012 a gerência da usina se reuniu com os operadores de carregadeiras para informá-los da possibilidade de desemprego em massa em razão das novas colheitadeiras. Como a cana cortada mecanicamente é jogada direto no transbordo, não haveria mais a necessidade da empresa contratar tantos operadores de carregadeiras. Ele nos informou que nessa mesma safra, a usina Sinimbu ficou 12 horas sem moer, em decorrência da paralisação de suas sete máquinas colheitadeiras que, nesse dia, estavam em manutenção ou em conserto.

A usina Sinimbu, que foi pioneira no plantio de cana nos tabuleiros alagoanos (ANDRADE, 1959), tem grande parte dos seus canaviais situada em terras planas ou com pouca declividade, possibilitando a realização do corte mecanizado. Todavia, do total da área plantada de Alagoas, apenas 61\% têm aptidão à mecanização do corte (IBGE, 2006 Apud TORQUATO \& FRONZAGILA \& MARTINS, s.d.). Ou seja, o limite técnico atual impossibilita que $39 \%$ da área plantada sejam cortadas mecanicamente.

Esses fatores indicam que não haverá extinção do corte manual da cana em um curto prazo. Ademais, é necessário levar em consideração se a mecanização em massa seria viável para os usineiros, pois, como já foi salientado anteriormente, o valor da força de trabalho do cortador em de cana em Alagoas é muito baixo, além disso, a agroindústria canavieira alagoano utiliza métodos característicos do que Harvey (2004) denominou como “acumulação por espoliação". Mas, ainda existe uma questão pendente: por que algumas usinas de Alagoas estão comprando máquinas colheitadeiras? O depoimento abaixo, de uma ex-cortadora de cana dos canaviais paulistas, nos fornece algumas pistas:

Naquela época [nos anos 1980], a gente podia lutar por alguns direitos que a gente queria, e alguns direitos que a gente tem aí, a gente brigou muito e conseguiu. Hoje, se você for lutar por melhores condições de vida, ou por qualquer direito que a gente queira, você fica desempregado. Porque tem as máquinas para trabalhar. Se não tiver o nosso serviço, tem o serviço das máquinas. Eles colocam as máquinas. Então, às vezes, a pessoa é obrigada a aceitar ganhar aquele pouco, porque é muito melhor ganhar pouco do que ficar sem nada (FRAGMENTOS [documentário dirigido por Maria Aparecida de Moraes Silva], 2011).

\footnotetext{
${ }^{36}$ A usina Sinimbu fica localizada no município alagoano de Jequiá da Praia, que também faz parte da Microrregião dos Tabuleiros de São Miguel dos Campos.
} 
Assim como as "máquinas monstros" (SILVA, 1999) foram empregadas como resposta dos usineiros às greves de São Paulo nos anos 1980, as máquinas moventes vieram para tentar demover os movimentos de greves e paralisação nas usinas de Alagoas. Como tem sido demonstrado em estudos sobre os canaviais paulistas, o forte avanço da mecanização da colheita não está resultando em total eliminação do trabalho manual, porém em novos rearranjos no mercado de trabalho e também nos métodos de exploração da força de trabalho. Parte significativa das mulheres canavieiras de São Paulo, por exemplo, trabalha atualmente em novas atividades que surgiram em decorrência da mecanização, como a catação de pedras. Vivenciase uma passagem: de cortadoras de cana à "faxineiras dos canaviais" (SILVA, 2011).

No caso de Alagoas, a nossa hipótese é que o processo de mecanização da colheita não implicará o fim do corte manual da cana em curto prazo (não somente pelos atuais limites técnicos), pois, os usineiros objetivam manter o corte manual de modo que: 1) intensifique ainda mais o trabalho do cortador de cana; 2) garanta que a usina moa cana mesmo em casos de paralisações e greves dos cortadores; 3) rebaixe o valor da força de trabalho do canavieiro (que já é superexplorada ${ }^{37}$ ). Se isso vai se concretizar? Como já demonstrou a história, depende dos rumos da luta de classes.

\section{Considerações finais}

Ainda que envolvidos em uma correlação de forças extremamente desfavorável, os trabalhadores canavieiros resistem, tanto em ações individuais e ocultas (boicotando os padrões do corte, burlando as normas disciplinares, sabotando o canavial, etc.), quanto em formas de lutas coletivas e públicas. Apesar dos limites dessas ações, que combatem os efeitos da exploração-dominação da força de trabalho, mas não as suas causas, essas práticas de resistência são fundamentais para minimizar a degradação do trabalho e para possibilitar que as lutas sejam elevadas a um patamar que questione o próprio trabalho assalariado e seus fundamentos.

Em resposta às greves e paralisações de 2007 a 2011, que objetivavam melhorar as condições de trabalho e alterar a forma de contratação da força de trabalho, alguns

\footnotetext{
37 Conforme aponta Marini (2005: 156), “a intensificação do trabalho, a prolongação da jornada de trabalho e a expropriação de parte do trabalho necessário ao operário para repor a sua força de trabalho" são características da superexploração do trabalho. Nos canaviais o primeiro e último desses mecanismos de exploração ocorrem de modo combinado. Ou seja, tanto o trabalhador tem a sua força de trabalho prematuramente desgastada pela alta intensidade do trabalho, quanto o trabalho é remunerado abaixo do seu valor.
} 
usineiros reagiram com o emprego de mais máquinas colheitadeiras. Com isso, nas usinas que adotam o corte mecanizado, não basta que os cortadores de cana entrem em greve para paralisar a produção de açúcar e álcool, pois, as máquinas colheitadeiras possibilitam que a usina continue sendo abastecida com canas cortadas. Nesse novo quadro, se as greves e paralisações dos cortadores de cana não forem articuladas ao conjunto dos trabalhadores dessa agroindústria (especialmente com os operadores de colheitadeiras), elas tendem a perder força.

O fato de as últimas greves e paralisações dos canavieiros terem sido organizadas à revelia dos sindicatos, sem o apoio de trabalhadores de outras atividades dessa agroindústria e de organizações dos trabalhadores de outros setores da economia, não ilustra somente a falência dos sindicatos de trabalhadores rurais, mas, também, a debilidade da esquerda alagoana que poderia estar efetivamente apoiando a luta pela melhoria das condições de trabalho dos canavieiros. As ações grevistas desses trabalhadores em Alagoas nem foi produto da atuação de uma organização política externa e nem produziu uma organização política permanente dos canavieiros.

Os movimentos de luta pela terra empreendidos por organizações como: MST, CPT, MLST, MTL e LCP em Alagoas, que já organizaram um expressivo número de trabalhadores em acampamentos e assentamentos, os partidos de esquerda e o movimento estudantil, poderiam se tornar pontos de apoio essenciais para $o$ fortalecimento das ações de resistência dos canavieiros. Mas para que essa frente se torne concreta, essas forças não podem se relacionar com os canavieiros apenas e enquanto eles possam ser imediatamente úteis para os seus programas específicos. Para que essa frente se torne efetiva, o ponto de partida deve ser a luta contra os problemas mais imediatos dos trabalhadores canavieiros. Desse modo, os partidos e os movimentos não estariam apenas apoiando esses trabalhadores, mas, sobretudo, ouvindo e aprendendo em meio a construção de uma luta que pode atacar diretamente o núcleo de produção de mais-valia dos capitalistas que dirigem o Estado em Alagoas: os usineiros.

\section{Referências}

ALBUQUerQue, Cícero Ferreira de. Casa, Cana e Poder. Maceió: EDUFAL, 2009.

ALVES, Francisco José da Costa. Modernização da agricultura e sindicalismo: lutas dos trabalhadores assalariados rurais da região canavieira de Ribeirão Preto. Campinas, 1991. Tese de Doutorado - Universidade de Campinas. 
Migração de trabalhadores rurais do Maranhão e Piauí para o corte da cana em São Paulo. In: Migrantes: trabalho e trabalhadores no complexo agroindustrial canavieiro (os heróis do agronegócio brasileiro). NOVAES, José Roberto e ALVES, Francisco (Orgs.). São Carlos: EdUFSCar, p. 21-54, 2007.

Políticas públicas compensatórias para a mecanização do corte da cana crua: indo direto ao ponto. In: RURIS, Vol. 3, N.1, Campinas, p. 153-178, 2009.

ANDRADE, Manuel Correia de. Os rios-do-açúcar no nordeste oriental: IV Rios Coruripe, Jequiá e São Miguel. Publicações do Instituto Joaquim Nabuco de Pesquisas Sociais. Recife: Imprensa Oficial, 1959.

BERTOLDO, Edna et al. Trabalho e educação dos trabalhadores do corte da cana: uma análise do contexto da modernização do setor sucroalcooleiro em Alagoas. In: Trabalho e Capitalismo Contemporâneo. PLANCHEREL, Alice \& BERTOLDO, Edna (Orgs). Maceió: EDUFAL, p.131-135, 2011.

CANDIDO, Paulo \& MALAGODI, Edgard. Mobilização de Trabalhadores Canavieiros e Ação Estatal no Setor Sucroalcooleiro do Nordeste Brasileiro. Porto de Galinhas: GT 21 ALASRU, 2010. Fonte: www.alasru.org. Acesso em 15 de fevereiro de 2011.

CARVALHO, Cícero Péricles de Oliveira. Análise da reestruturação produtiva da agroindústria sucroalcooleira alagoana. Maceió: EDUFAL, 2000.

COVER, Maciel. O "Tranco da Roça" e a "Vida no Barraco": um estudo sobre trabalhadores migrantes no setor do agronegócio canavieiro. Campina Grande, 2011. Dissertação de Mestrado. Universidade Federal de Campina Grande.

HARVEY, David. O novo imperialismo. São Paulo: Edições Loyola, 2004.

INFORMATIVO DO SINDAÇÚCAR-AL. Coluna AGORA, Usinas investem em mecanização de colheita da cana, 4 de Nov. de 2011. Disponível em: http://www.sindacucar-al.com.br/coluna_agora/colunas bd/4112011 202.pdf . Acesso em: jan. de 2012.

LAAT, Erivelton Fontana de. Trabalho e risco no corte manual de cana-de-açúcar: a maratona perigosa nos canaviais. Tese de Doutorado. Programa de Pós Graduação em Engenharia de Produção da Universidade Metodista de Piracicaba. Santa Bárbara d' Oeste - SP, 2010.

LUXEMBURGO, Rosa de. Greve de Massas, Partido e Sindicatos. In: Rosa de Luxemburgo: textos escolhidos: Volume I. Org. Isabel Loureiro. São Paulo: Editora Unesp, p. 263-349, 2011. 
MARINI, Rui Mauro. Dialética da dependência. In: Rui Mauro Marine vida e obra. Orgs João Pedro Stedile e Roberta Transpadini. São Paulo: Expressão Popular, 2005

MARX, Karl.Salário, preço e lucro. In: MARX, Karl; Para a crítica da economia política; Salário, preço e lucro; $O$ rendimento e suas fontes: a economia vulgar. São Paulo: Abril Cultural, 1982.

. O Capital. /Livro Primeiro, Tomo 2. São Paulo: Nova Cultural, 1985.

MELLO, Paulo Décio de Arruda. Cana-de-açúcar e reestruturação produtiva: ação sindical e os movimentos sociais rurais em Alagoas a partir de 1985. Recife, 2002. Tese de doutorado. Programa de Pós-Graduação em Sociologia da Universidade Federal de Pernambuco.

MENEZES, Marilda Aparecida. Redes e enredos nas trilhas dos migrantes: um estudo de família de camponeses migrantes. João Pessoa, PB: EDUFPB, 2002.

NOVAES, José Roberto. Idas e Vindas: disparidades e conexões regionais. In: Migrantes: trabalho e trabalhadores no complexo agroindustrial canavieiro (os heróis do agronegócio brasileiro). Org. José Roberto Novaes e Francisco Alves. São Carlos: EdUFSCar, p. 87-118, 2007.

PADRÃO, Luciano Nunes. O trabalho na cana-de-açúcar, reestruturação produtiva e novas práticas gerenciais. 1997. Disponível em: http://www.seade.gov.br/produtos/ spp/v11n01/v11n01_14.pdf. Acesso em: 11 dez. 2008.

PLANCHEREL, Alice Anabuki \& QUEIROZ, Allan Souza \& SANTOS, Charles dos. O "canguru" no universo canavieiro alagoano: saúde e precarização do trabalho na agroindústria açucareira. In: Trabalho e Capitalismo Contemporâneo. PLANCHEREL, Alice \& BERTOLDO, Edna (Orgs). Maceió: EDUFAL, p5980, 2011.

QUEIROZ, Allan Souza. Modernização, reestruturação produtiva e precarização do trabalho nos canaviais. Monografia de Conclusão do Curso de Ciências Sociais (UFAL). Maceió, 2011.

SANTOS, Sérgio Silva dos. O cultivo da cana no Estado de Alagoas: uma análise comparativa do estado de São Paulo. Brasília, 2011. Dissertação de mestrado. Centro de Desenvolvimento Sustentável. Universidade de Brasília.

SCOTT, James C. Formas Cotidianas da Resistência Camponesa. In: Raízes: revista de ciências sociais e econômicas/ Universidade Federal de Campina Grande, Programa de Pós-Graduação em Sociologia - Vol. 1, n. 01. Campina Grande, 1982.

SILVA, Maria Aparecida de Moraes. Errantes do fim do século. São Paulo: Editora UNESP, 1999. 
. Trabalho e trabalhadores na região do "mar de cana e do rio de álcool". In: Migrantes: trabalho e trabalhadores no complexo agroindustrial canavieiro (os heróis do agronegócio brasileiro). Org. José Roberto Novaes e Francisco Alves, São Carlos: EduFSCar, p. 55-86, 2007.

. Cortadores de Cana e os (Não) Direitos. In: TRAVESSIA revista do migrante. Publicação CEM - Ano XXI, número 61, Maio- Agosto/, p.26-36 2008.

. O trabalho oculto nos canaviais paulistas. In: Perspectivas, São Paulo, v. 39, p. 11-46, 2011.

THOMPSON, E. P. A Miséria da Teoria ou um Planetário de Erros. Rio de Janeiro: Zahar Editores, 1981.

TORQUATO, Sergio Alves, FRONZAGILA, Thomaz e MARTINS, Renata- Colheita Mecanizada e Adequação da tecnologia nas regiões produtores de cana de açúcar.

Disponívelem:http://www.alice.cnptia.embrapa.br/bitstream/doc/855892/1/1SCo lheitaMecanizada/AdequacaoTecnologia Acesso em: 24 de julho de 2011.

VERÇOZA, Lúcio Vasconcellos de. Labor nos "eitos gigantes": a superexploração da força de trabalho nos canaviais de Alagoas. In: Trabalho e Capitalismo Contemporâneo. PLANCHEREL, Alice \& BERTOLDO, Edna (Orgs). Maceió: EDUFAL, p. 81-106, 2011. 